\title{
THE USE OF SOFT SYSTEM METHODOLOGY TO BUILD A CONCEPTUAL MODEL FOR STRENGTHENING INNOVATION OF ENTREPRENEURS IN COASTAL AREA OF JAKARTA
}

\author{
Rina Uswatun Hasanah")1, M. Syamsul Maarif*, Nimmi Zulbainarni*), and M. Joko Affandi**) \\ *) School of Business, IPB University \\ Jl. Raya Pajajaran, Bogor 16151, Indonesia \\ ${ }^{* *}$ PPM Jakarta \\ Jl. Menteng Raya 9-19, Menteng, Jakarta Pusat 10340, Indonesia
}

\begin{abstract}
Strengthening innovation for entrepreneur is very important because nowadays consumers are smarter and they demand to meet their needs in terms of quality, renewal and price. Small businesses and beginners are often unable to achieve business sustainability. Therefore, innovative capabilities are needed to meet consumer's needs and to achieve business sustainability. By using an entrepreneurial ecosystem approach through elements of actors, factors, enthusiasm and interrelated processes that can strengthen the innovation of entrepreneur. The main purpose of this paper is to analyze the dynamics of entrepreneurial innovation so that factors to strengthen innovation can be identified. This study uses Soft System Methodology (SSM) through the application of SSM steps to obtain a conceptual model to strengthen innovation for entrepreneur. This research was conducted for 6 months, by conducting in-depth interviews with 50 respondents consisting of government, academics, community leaders and business actors. The results showed that a strong will from within the entrepreneur and the use of technology are key factors in strengthening entrepreneurial innovation.
\end{abstract}

Keywords: coastal area, conceptual model, entrepreneur, innovation, soft system methodology

Abstrak: Penguatan inovasi bagi wirausahawan sangat penting karena konsumen saat ini semakin pintar dan menuntut untuk memenuhi kebutuhannya baik dari segi kualitas, pembaharuan dan harga. Bisnis kecil dan pemula seringkali tidak dapat mencapai keberlanjutan bisnis, oleh karena itu diperlukan kapabilitas inovatif untuk memenuhi kebutuhan konsumen dan mencapai keberlanjutan bisnis. Dengan menggunakan pendekatan ekosistem kewirausahaan melalui elemen aktor, faktor, semangat dan proses yang saling terkait dapat memperkuat inovasi wirausaha. Tujuan utama dari makalah ini adalah untuk menganalisis dinamika inovasi wirausaha sehingga dapat diketahui faktor-faktor yang memperkuat inovasi. Penelitian ini menggunakan Soft System Methodology (SSM) melalui penerapan langkah-langkah SSM untuk mendapatkan model konseptual yang mampu memperkuat inovasi bagi wirausaha. Penelitian ini dilakukan selama 6 bulan, dengan melakukan wawancara mendalam kepada responden pakar sebanyak 50 orang yang terdiri dari pemerintahan, akademisi, tokoh masyarakat dan para pelaku usaha. Hasil penelitian menunjukkan bahwa kemauan yang kuat dari dalam diri wirausaha dan kemampuan penggunaan teknologi merupakan faktor kunci dalam memperkuat inovasi wirausaha.

Kata kunci: wilayah pesisir, model konseptual, wirausaha, inovasi, soft system methodology

${ }^{1}$ Corresponding author:

Email: uswahrina@gmail.com 


\section{INTRODUCTION}

Jakarta as the capital city has a coastal area directly adjacent to the Java Sea, known as Jakarta Bay. Administrative City of North Jakarta is one of the regions in the capital with the sea as its borders. Based on the map of the industrial estate and ports in the Jakarta Bay area, there are six districts bordering the sea in Capital City of Jakarta, including Penjaringan, Pademangan, Tanjung Priok, Koja, Cilincing, and other small islands. The three districts of Tanjung Priok, Koja and Cilincing are areas with heavy industrial population. Tanjung Priok and Cilincing Subdistricts are trade centers because Tanjung Priok Port, the busiest port in Indonesia, is located there. Not only that, the Cilincing Fish Auction Place (TPI Cilincing) is one of the fishing boat ports in the Jakarta Bay and is also located right on the edge of the Cilincing Waterway. Aside from being a river mouth, Cilincing Waterway is also used as a location for large ships to rest in a warehousing company called Kawasan Berikat Nusantara. Kawasan Berikat Nusantara is one of the large-scale industrial activities in the Cilincing area.

The great potential of North Jakarta is not proportional to the growth of entrepreneurs in the region. Most businesses in North Jakarta are micro (small) which also gives smaller chance to open new employment (Ananda and Susilowati, 2017), it means they need a lot of innovation that is sufficient to produce a wellestablished entrepreneurship. From the aspect of human resources, the ability of entrepreneurs in implementing innovation is seen as insignificant. Many entrepreneurs want to apply innovation in their business organizations, but the innovation cannot just appear by itself, as it's not equipment that can be purchased and can be used directly (Hutahean, 2005). Innovation is about putting ideas into realization, including a series of idea-based improvement processes, technological change, and the increase in activities of organizational, financial and commercial (Malecki, 1997).

Entrepreneurship is a driving factor in strengthening the Indonesian economy. The experience of the economic crisis in Indonesia in 1998 and the 2008-2009 global crisis showed that on one hand, many large companies underperformed and even closed; but on the other hand, new businesses in small and medium scale can still grow and develop (Tambunan, 2010). The characteristics of small businesses and growing businesses make them more flexible in responding to changes, which are manifested in the form of business diversification or switching to a different type of business. Their growth can have a positive impact on the country's economic development, especially in employment creation, as well as the development of innovation, and social values (Singer et al. 2015).

One indicator of a country's economic resilience can be seen from the ratio of the number of entrepreneurs to the total population. On average, a developed country with stable economy have a ratio of 14 percent, or 14 percent of the population in the country are entrepreneurs. While in Indonesia, the ratio of the number of entrepreneurs is still low, although from year to year the number shows an upward trend. Data from the Badan Pusat Statistik (BPS) in 2017 reported that the number of entrepreneurs in Indonesia reached 3.1 percent of the population at the end of 2017. This percentage is still lower when compared to neighboring countries like, for example, Malaysia which has more than 5 percent and Singapore with more than 7 percent.

Innovation is very important for many things in entrepreneurship, including success and longevity. But being innovative is not easy, because not many people are able to do it. Drucker (1985) states that there are several needs that must be done in creating innovation, namely having systematic goals with the ability to analyze opportunities, conceptual and perceptual, simple and focused, doing something unique and leadershiporiented. Entrepreneurs are often diligent, resilient, creative people, always think ahead and have clear goals for themselves or others. However, innovation for business actors in the coastal areas of Jakarta has not been maximally implemented (Simbolon, 2017). So the strengthening of entrepreneurial innovation on the coast is something that must be considered by stakeholders.

The purpose of this study is to analyze the dynamics of entrepreneurial innovation and build a conceptual model for strengthening entrepreneurial innovation in coastal areas. The phenomenon that occurs is the limited development of businesses in the coastal areas, especially in the Cilincing, Tanjung Priok and Koja Districts, which is caused by the lack of facilities and infrastructure as well as the low quality of the population, seen from the low level of community education, both formal and informal education. However, this area is the most accessible because it is geographically the easiest to find and has a low cost of living. Of course 
this is homework for local governments to be able to increase the number of established entrepreneurs in coastal areas. It takes a lot of innovation to produce entrepreneurs who are capable of being independent and well established.

\section{METHODS}

The location of the research was conducted in Indonesia, focusing on the coastal area of Jakarta in Koja, Tanjung Priok and Cilincing district, with data collection time of 6 (six) months. This study uses a qualitative approach with the types of data used are primary and secondary data. Data collection techniques are carried out through in-depth interviews and Focus Group Discussions (FGD) to further explore a number of problems and data that are not summarized in indepth interviews, and through documentation, namely data collection obtained through reports or documents and other information. The number of respondents was 50 people consisting of the government, academics, local community leaders and business actors in the North Jakarta City area focusing on Tanjung Priok, Koja and Cilincing Districts who were chosen deliberately based on different types of business, including trading of seafood, culinary products, transportation, home stalls, accessories, fashion, and the seafood processing industry.

This study uses a soft system methodology which aims to find a conceptual model for strengthening innovation based on the characteristics of business actors. Soft Systems Methodology is used as an analysis step that is more experienced-based knowledge, meaning that it emphasizes the importance of extracting information and the desires of actors in the real world so that it can then be formulated into recommendations in order to improve the problematic situations that are the target of research (Hardjosoekarto, 2012).

In this study, the analysis was carried out through the application of the seven steps in the SSM approach. The first step is situational analysis of the context of the problem at hand. In this initial stage, researchers want to see the dynamics of innovation from entrepreneur. The second step is to find out what the problems are related to various interested parties in terms of their needs, role, activities and responsibilities. The output of this stage is in the form of Rich Picture, which illustrates the relationship between one party and another. The third step is defining each group's role in an approach called CATWOE (Client or Customers, Actors, Transformations, World view, Owner and Environment constraint). The fourth step is to design a conceptual model that explains the relationship between other activities. Conceptual models describe the input-process-output relationship between one activity and another. The fifth step is to arrange the agenda of activities that will be carried out in real time in the field and at the same time make a comparison between the real world and the conceptual model that has been designed previously. The sixth step defines the changes that are likely to be implemented. Debate between experts will be very possible at this stage. Some changes that might occur include changes in procedures, changes in structure or changes in attitudes and culture in the form of changes in values, norms or ways of thinking. The seventh step is to take corrective actions especially on the models that have been built. The process in SSM does not end here, but continues to make improvements to the model as the environment changes.

Through this approach, we can learn through reflection of consciousness. Checkland and Scholes (1990) stated that to be able to build knowledge from these experiences an SSM practitioner must be grounded in the conceptual framework and theory that became the author's standing position before the research was conducted. It is intended that the involvement of us as SSM practitioners with problematic situations can be defined. The research framework is like a Figure 1.

\section{RESULTS}

\section{The Dynamics of Entrepreneurial Innovation}

In the context of forming a business, an entrepreneur experiences enormous uncertainty and a high level of complexity as a challenge of his task (McMullen and Shepherd, 2006). To anticipate these problems, an entrepreneur must have passion (Winnen, 2005). Passion is believed to be able to encourage the early stage entrepreneurs to work hard to achieve certain final goals while passion can prevent early stage entrepreneurs from leaving their businesses (Wicker and Davidson, 2015). Vallerand et al. (2003) explained that passion is a strong tendency towards an activity that is considered important, preferred (even loved) in which they will invest most of their time and energy. 
Smilor (1997) considers that passion is an emotional state such as feelings of enthusiasm, excitement, and spirit.

Many ways and factors that could influence small entrepreneurs to upgrade to a certain level. One way that can be done is through innovation, such as product innovation, improving the quality of the production process (process innovation), increasing marketing performance (marketing innovation), business transformation to a higher level (functional innovation), and moving to a new sector (sectoral innovation). Drucker (1985) explained innovation is a specific tool for entrepreneurs, the way they exploit change as opportunities for different businesses or services, it can be viewed as a discipline, and can be learned and practiced. Innovation is novelty regarding products, processes, production methods, and technology (Varis and Littunen, 2010). An analytical framework is needed for an innovation system that can uncover the broadest possible ideas about strengthening innovation as a new solution that has been successfully embedded in society in terms of technology, products, social practices, processes and new concepts (Warnke et al. 2016).

The development of entrepreneurial innovation can be done through an entrepreneurial ecosystem approach. The entrepreneurial ecosystem is defined as a community of entrepreneur and interdependent factors (Freeman and Audia, 2006). The World Economic Forum (2014) defines the entrepreneurial ecosystem as a system that has interrelated pillars that have an impact on the speed and ability of entrepreneurs to create and develop their businesses sustainably. According to Isenberg (2011) there are seven pillars of the entrepreneurial ecosystem as follows:

1. Cultural Pillars which include components of social norms and dissemination of best practices that can used as role models or sources of inspiration.

2. Pillars of human resources (HR). A skilled and trained workforce, as well as parents or entrepreneurial family background are among the factors which shape the entrepreneurial ecosystem.

3. Educational Pillars which include education and training components. Technical and vocational training are also important factors in the entrepreneurial ecosystem.

4. Funding Pillars. Financing required can include credit for MSMEs, investment cooperation opportunities, venture capital, capital markets and various other forms of financing.

5. Market Pillar which covers the network and consumer responsiveness.

6. Policy Pillars which include government policies and leadership.

7. Supporting Pillars which include components related to the role of non-Government institutions, professional institutions and infrastructure.

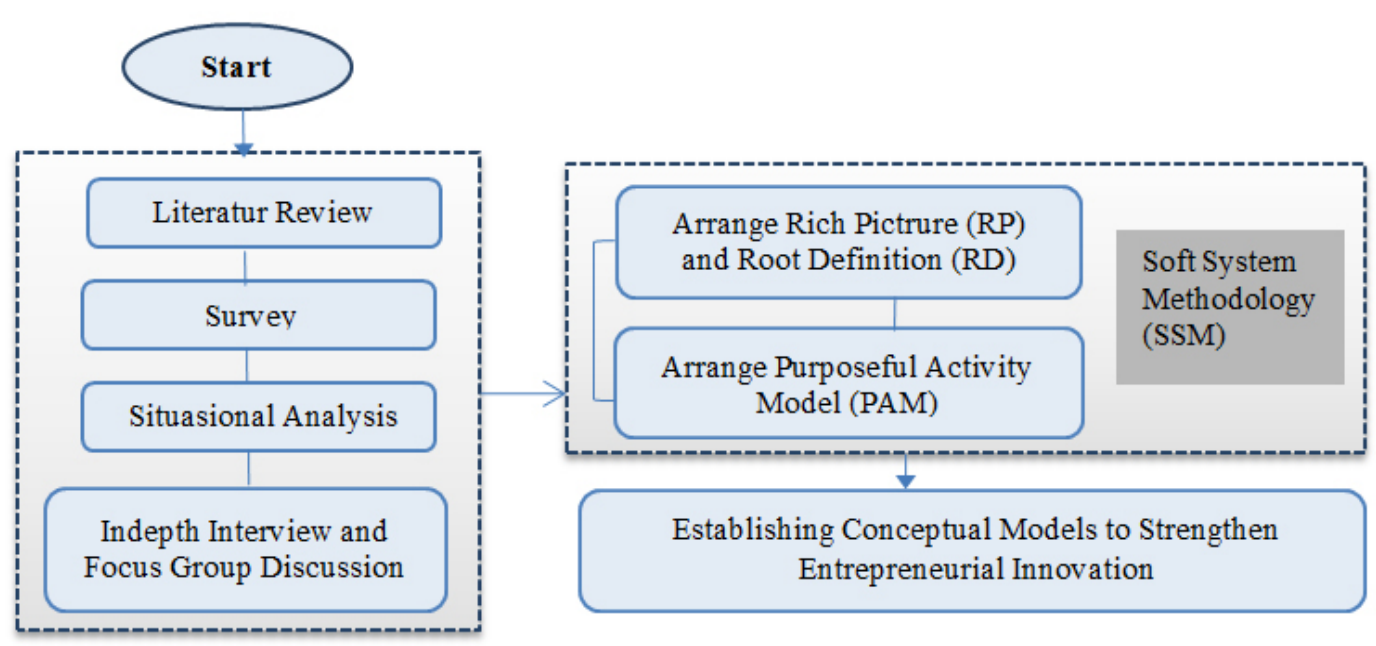

Figure 1. Research framework 
There is a relationship between entrepreneurial ecosystems with clusters, industrial estates and innovation systems (Stam and Spigel, 2016). An innovation system includes all economic, social, politic, organizational, institutional, and other factors that influence the development, diffusion, and use of innovation (Edquist, 2001). Market players, government and social communities also have a dominant role in the process of knowledge transfer related to improving the quality of entrepreneurship (Purbasari et al. 2020), including the social environment and perceived emotional support that can increase entrepreneurial enthusiasm (Stenholm et al. 2019).

De Jong (2007) states that there are four dimensions of innovative behavior: 1) Seeing opportunities, innovative processes are determined by opportunities. Opportunities will trigger individuals to look for ways to improve service, delivery processes, or try to think of a new alternative regarding work processes, products or services. 2) Finding an idea, generating a concept for improvement. Finding ideas is the management of information and concepts that have been there to improve performance. Individuals who are high in this level will be able to see the solution of a problem with a different way of thinking. 3) Striving and be involved to find support and build coalitions, such as inviting and influencing employees or management, and negotiating about a solution. 4) Application, individuals not only think about creative ideas about a thing but also apply those ideas into concrete actions, individual creative ideas that are protected by copyright law.

There is a positive influence on entrepreneurial competency variables, the use of information technology, and innovation on company competitive advantage (Dahlia et al. 2015). Sondari (2013) states a company will be more innovative if supported by competent, creative human resources and get good training to develop its competence. Other studies suggest that competence is related to superior performance under any circumstances (Hayton and Kelley, 2006) and that successful businesses are led by competent owners (Chandler and Jansen, 1992). Entrepreneurs with superior task-related competencies in the form of entrepreneurial experience are better able to translate and transform perceived emotional support into entrepreneurial passion (Stenholm and Nielsen, 2019).

\section{Conceptual Model for Strengthening Entrepreneurial Innovation in Coastal Areas}

Based on data obtained from the Ministry of Cooperatives and SMEs (KUKM) of North Jakarta, there are 4467 entrepreneur who received guidance programs from the government. Businesses in the three sub-districts have benefited from training education, technical guidance, business assistance, capital assistance, licensing and product marketing. The results of this research are based on SSM analysis through the following stages :

\section{The Stage one - Situation Considered Problematic}

Entrepreneurs in North Jakarta, especially in the three sub-districts of Koja, Tanjung Priok and Cilincing have limitations, including not all entrepreneurs can use technology for business development, capital and marketing access that are difficult to obtain, lack of innovation and a less supportive environment, including lack of motivation. As research from Simbolon (2017) which states that only 18 percent of the Cilincing coastal community are able to see opportunities to open new businesses, even though when viewed from the age category, the majority of the Cilincing Coastal community is aged 35-45 years, meaning this age is of productive age. This is because the Cilincing coastal community does not use information technology as a means of increasing their knowledge and marketing.

The limitations of business palsy can be strengthened through the maximization of actors in the entrepreneurial ecosystem. Several important actors who play a role in efforts to increase innovation capabilities are the DKI Jakarta City Government, in this case the Industry and Trade Office of Small and Medium Enterprises and the Office of Marine and Agricultural Food Security which has made efforts to provide training programs, mentoring, socialization and technical guidance. including the convenience for entrepreneurs to obtain business licenses. The role of academics in providing an understanding of science and practice can increase competencies which have an impact on increasing innovation capabilities. The role of the social environment in providing increased knowledge of current information and views to get innovative ideas through active participation in an organization and the business community. The role of the family in providing motivation for business development and the role of consumers in providing input and ideas 
that are relevant and needed today. This is in line with the results of research by Ratumbuysang and Rasyid (2015) which states that there is a significant influence between the role of parents, the environment, and learning entrepreneurship together on entrepreneurial readiness.

\section{Stage two - Problem Situation Expressed}

From the explanation in step one, we can draw a Rich Picture like Figure 2.

\section{Stage three-Root Definitions of Relevant Systems}

At this stage, we make Root Definition based on Rich Picture in stage two. As for making Root Definition follow the PQR formula, a system to do P by Q in order to achieve R (Hardjosoekarto, 2012). Root Definition in this research is strengthening entrepreneurial innovation is an innovation system that involves all elements to make improvements and improvements conceptually and technically $(\mathrm{P})$ through a measured entrepreneurial ecosystem approach $(\mathrm{Q})$ so that it is more focused on economic, social and environmental goals (R). The next step is to define CATWOE (Client or Customers, Actors, Transformations, World view, Owner dan Environmental constraint) as follows: C (Business operators, customers), A (Business actors, researchers, academics, government, family, mentor), $\mathrm{T}$ (Weak entrepreneurial innovation abilities $\rightarrow$ increase the innovation capabilities of the actors business through an entrepreneurial ecosystem approach with sustainable business objectives), W (Collaboration between elements in the entrepreneurial ecosystem will provide benefits for business actors to achieve sustainable businesses), O (Local / regional business actors and government), E (Culture, mindset, competence, access to information).

\section{Stage four - building conceptual model}

The conceptual model must be constructed from words written in the root definition without reconnecting with certain situations. We must use words that can describe the activities in the transformation process that are precisely describes. The conceptual model must be accounted for. At this stage a conceptual model is generally made as follows (Figure 3 ).

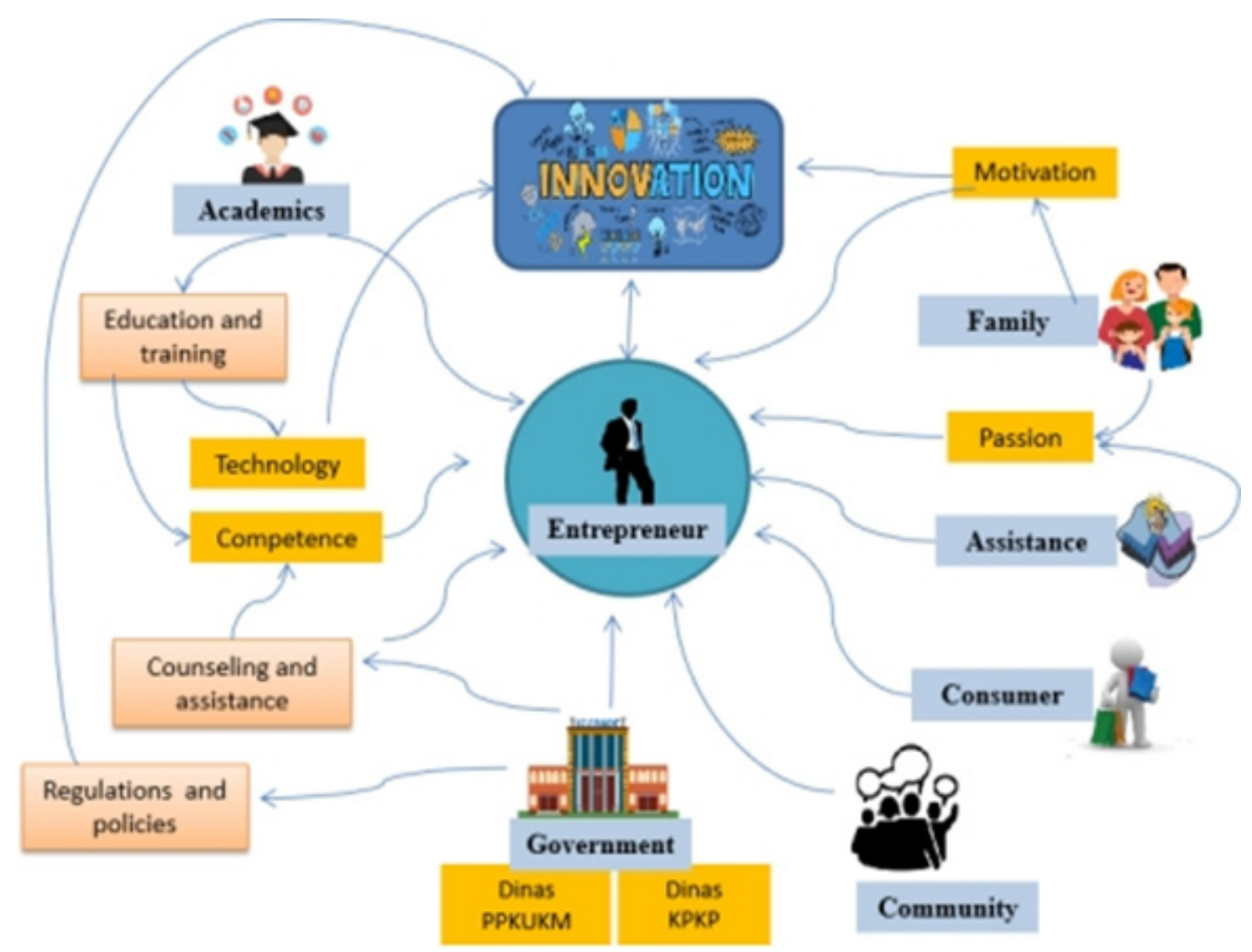

Figure 2. Rich Picture 


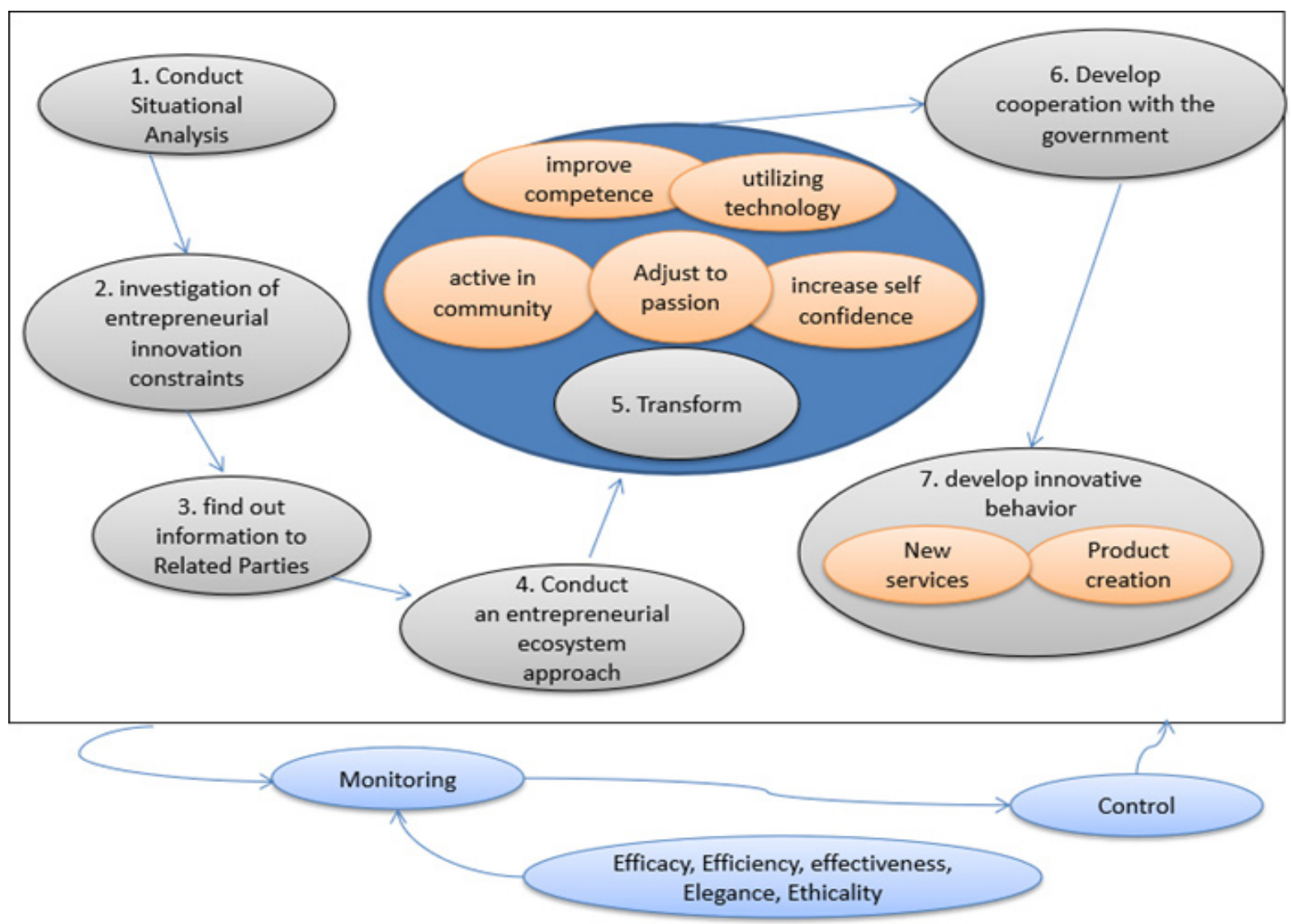

Figure 3. Conceptual model

\section{Stage five and six - Back in the real world and define the changes to be implemented}

To find out the results of the implementation of the system design that has been built, further steps are arranged in the form of a comparative analysis between the targets desired by the system and the reality that occurs in the field. First, make notes on the differences that exist from the results of the implementation that has been done. Second, set comparison criteria, then proceed with the assessment and analysis activities for deviations that exist from the expected target. Third, operation of the system by compiling scenarios that have occurred in the past, then run the scenario on the model that has been built, and analyze whether the model has been running as expected by current conditions. Fourth, see whether the model that has been built has provided answers to the expected solutions. Comparison of conceptual models with the real world in this study as in Table 1.

\section{Stage seven - Taking action}

After the model meets the requirements of reality and logic, the next step is to carry out actions in finding the best solution that meets the various interests that exist. The last stage of the Soft System Methodology framework is the making of suggestions and strategies for the desired change. In this stage, the process of determining the desired action is carried out by determining the key factors.

Based on the results of the FGD and interviews conducted with several informants and entrepreneur, it was found that the determinants of strengthening entrepreneurial innovation were the willingness of entrepreneur for change and utilize technology. Previous research related to the importance of this information such as research by Jabeur et al. (2013) stated that today's business environment demands to use information technology (IT) to remain competitive. Technology is also part of the solutions needed to meet opportunities. An entrepreneur must identify and seek market opportunities, find solutions to fill these market opportunities, obtain the necessary resources (money, people, and equipment) to run the business, resources from the initial stage to the survival phase and the development phase (expansion), and the risks associated with its business. 
Table 1. Comparison model conceptual

\begin{tabular}{|c|c|c|}
\hline Conceptual Model & Description of real-world activities & Real World Activity Outputs \\
\hline Conduct situational analysis & $\begin{array}{l}\text { Conduct an investigation in the } \\
\text { area of research covering the social } \\
\text { environment, culture and human } \\
\text { resource characteristics }\end{array}$ & $\begin{array}{l}\text { Environmental documentation and } \\
\text { profile }\end{array}$ \\
\hline Investigating innovation constraints & $\begin{array}{l}\text { Look for factors that constrain } \\
\text { innovation }\end{array}$ & $\begin{array}{l}\text { Discover the factors that strengthen } \\
\text { innovation }\end{array}$ \\
\hline $\begin{array}{l}\text { Looking for information from related } \\
\text { parties }\end{array}$ & $\begin{array}{l}\text { Conduct interviews with experts } \\
\text { related to business innovation }\end{array}$ & $\begin{array}{l}\text { Obtain information on the application } \\
\text { of ways to strengthen business } \\
\text { innovation }\end{array}$ \\
\hline $\begin{array}{l}\text { Conduct an analysis with an } \\
\text { entrepreneurial ecosystem approach }\end{array}$ & $\begin{array}{l}\text { Determine the actors and factors in } \\
\text { increasing entrepreneurial innovation }\end{array}$ & $\begin{array}{l}\text { Finding elements are important for } \\
\text { increasing entrepreneurial innovation }\end{array}$ \\
\hline Transform & $\begin{array}{l}\text { Increase competence, utilize } \\
\text { technology, be active in a community } \\
\text { or business organization, increase } \\
\text { confidence }\end{array}$ & $\begin{array}{l}\text { Competency improvement through } \\
\text { training education, technical } \\
\text { feedback, participation in the business } \\
\text { community }\end{array}$ \\
\hline $\begin{array}{l}\text { Establish cooperation with the } \\
\text { government }\end{array}$ & $\begin{array}{l}\text { Following the program organized by } \\
\text { the government }\end{array}$ & $\begin{array}{l}\text { Ease of licensing and knowledge } \\
\text { development }\end{array}$ \\
\hline Cultivating innovative behavior & $\begin{array}{l}\text { Have a strong desire to learn and be } \\
\text { creative }\end{array}$ & $\begin{array}{l}\text { Produce product and innovative } \\
\text { services }\end{array}$ \\
\hline
\end{tabular}

A dynamic entrepreneur will be willing to make changes by increasing competence through activities such as training education, technical guidance and mentoring as well as actively participating in community activities and business organizations. The use of technology can be done by taking the existing opportunities using technology and utilizing it as a medium of information and marketing. The social environment supports the ability to innovate and can influence the outcome of change. By doing this consistently will provide good results to increase the ability of entrepreneurial innovation.

The intended will is an attitude and awareness from within that is based on a strong desire called passion. Entrepreneur will be willing to make changes by increasing their competence through activities such as training education, technical guidance and mentoring as well as actively participating in community activities and business organizations. Utilization of technology can be done by looking at existing opportunities and using technology as a medium for information and marketing. Social environment supports the ability of innovation and can influence the results of change. By doing this consistently will give good results to increase the ability of entrepreneurial innovation.

\section{Managerial Implications}

From the research results it is known that the internal and external factors that determine the strengthening of entrepreneurial innovation. Internal factors include competence, motivation, use of information technology and passion. External factors are elements of the entrepreneurial ecosystem including adequate education and knowledge, skilled human resources who have a strong will to create new things and a culture of innovation. Willingness in question is an attitude and inner awareness that is based on a strong desire which is called passion. Based on this, the strategy of strengthening entrepreneurial innovation can be carried out by paying attention to determining factors and of course it will make it easier for local governments to manage coastal areas in the field of entrepreneurship.

\section{CONCLUSIONS AND RECOMMENDATIONS}

\section{Conclusions}

Based on the results of the study, it was found that strengthening the innovation of business actors can be done through self-potential development based on a willingness and enthusiasm for change. Through the entrepreneurial ecosystem approach, actors who 
play a role in increasing innovation can be identified, including business actors, researchers, academics, and the government. The factors that encourage the strengthening of innovation as the conceptual model in this study.

This research reveals that in the context of strengthening innovation there is an element of will called passion, which is believed to be able to anticipate the problems of a business actor when experiencing uncertainty and complexity in his job demands. Passion plays a role in product creation and development, business formation and business development (Meiriska and Meiyanto, 2017). This is in line with research conducted by Winnen (2005) and Smillor (1997) which states that passion can motivate entrepreneurs to achieve goals. Thus passion is a psychological condition characterized by strong positive emotions, internal drive and high involvement in business activities that are considered profitable.

\section{Recommendations}

Based on the SSM study in the fourth and fifth stages, researchers developed a conceptual model of strengthening entrepreneurial innovation through an entrepreneurial ecosystem approach which has pillars that become factors for strengthening entrepreneurial innovation. From these pillars produce entrepreneurial transformation to increase innovation. Then further research can explore each pillar in the entrepreneurial ecosystem such as human resources, culture, education, financing, markets, policies and other supports so that the transformation results are more detailed and focused. Future studies consider a larger number of respondents and different areas to study, because there will be different cultural factors and entrepreneurial characteristics that can produce different sensitive elements as reinforcing variables for entrepreneurial innovation.

\section{REFERENCES}

Ananda AD, Susilowati D. 2017. Development of Small and Medium Enterprises based on creative industry in Malang. Journal of economic science 10(10):120-142.

[BPS] Badan Pusat Statustik. Indonesia environmental statistics 2017. Jakarta: BPS.

Chandler GN, Jansen E. 1992. The founder's selfassessed competence and venture performance.
Journal of Business Venturing 7(3):223-236. https://doi.org/10.1016/0883-9026(92)90028-P.

Checkland P, Scholes J. 1990. Soft Systems Methodology in Action, include a 30 Year Retrospective. Chichester: J Wiley.

Dahlia, Patty M, Sutiksno DU. 2015. The impact of entrepreneurial competition, the use of information and technology, and innovation in competing towards Asean Economic Community 2015. Proceeding. Seminar for Graduate Student Union of Faculty of Economy and Business, Padjajaran University: Bandung.

De Jong J. 2007. Individual innovation : the connection between leadership and employee's innovative work behavior [Dissertation]. Amsterdam: Faculty of Economics and Business University of Amsterdam.

Drucker PF. 1985. Innovation and Entrepreunership Practice and Principles. New York: Harper and Row, Publiser Inc.

Edquist C. 2001. Innovation Policy in the Systems of Innovation Approach: some Basic Principles. In Fischer MM and J. Fröhllich (eds.) Knowledge, Complexity and Innovation Systems, Berlin: Springer Verlag.

Freeman JH, Audia PG. 2006. Community ecology and the sociology of organizations. Annual Review of Sociology 32: 145-169. https://doi.org/10.1146/ annurev.soc.32.061604.123135.

Hardjosoekarto S. 2012. Soft Systems Methodology. Jakarta: University of Indonesia Pr.

Hayton JC, Kelley DJ. 2006. A competencybased framework for promoting corporate entrepreneurship.Human Resource Management. 45(3):407-427. https://doi.org/10.1002/ hrm. 20118.

Hutahean ES. 2005. Contributions of Creativity and organizational climate to innovative behavior. Proceeding, National Seminar.

Isenberg, D. 2011. The entrepreneurship ecosystem strategy as a new paradigm for economic policy: Principles for cultivating entrepreneurship. Dublin, Ireland: Institute of International European Affairs.

Jabeur F, Mohiuddin M, Karuranga E. 2013. Timeline of initial perceptions and adoption of e-business among quebec forestry sector SMEs. Communications of the IIMA. 13(3):1-20.

Katz JA, Green RP. 2007. Entrepreneurial Small Business. New York: McGraw-Hill.

Malecki EJ. 1997. Entrepreneurs, networks, 
and economic development. Advances in Entrepreneurship, Firm Emerge and Growth 3(1): 57-118.

McMullen JS, Shepherd DA. 2006. Entrepreneurial action and the role of uncertainty in the theory of the entrepreneur. Academy of Management Review 31(1):132-52. https://doi.org/10.5465/ amr.2006.19379628.

Merieska P, Meiyanto IJK. 2017. Entrepreneurial passion in young entrepreneurs. Gadjah Mada Journal of Psychology 3(1): 13-24. https://doi. org/10.22146/gamajop.42394.

Purbasari R, Muhyi HA, Sukoco I. 2020. Actors and their roles in entrepreneurial ecosystem: a network theory perspective: cooperative study in Sukabumi, West Java. Review of Integrative Business and Economics Research 9(3):240253.

Ratumbuysang MFNG, Rasyid AA. 2015. The role of parents, the environment, and entrepreneurship learning on entrepreneurship readiness. Journal of Vocational Education 5 (1): 15-27.

Simbolon AR. 2017. Characteristics and Attitudes of Environmental Care for the Coastal Communities of the Cilincing Area, Jakarta. Pro-Life Journal 4 (3): 456-466

Singer S, Amorós JE, Arreola DM. 2015. Global Entrepreneurship Monitor 2014 Global Report: Global Entrepreneurship Monitor Association.

Smilor RW. 1997. Entrepreneurship: Reflections on a subversive activity. Journal of Business Venturing 12(5):341-346. https://doi.org/10.1016/S08839026(97)00008-6.

Sondari D, Maarif MS, Arkeman Y. 2013. Analysis of factors influencing the innovation of pegagan extract nanoencapsulation as a substance to treat cellulite. Journal of Industrial Engineering 3(1):54-63.https://doi.org/10.25105/jti. v3i1.1586.
Stam E, Spigel B. 2016. Entrepreneurial Ecosystems. Utrecth School of Economics. Tjalling C. Koopmans Research Institute. Discussion Paper Series 16-13.

Stenholm P, Nielsen MS. 2019. Understanding the emergence of entrepreneurial passion: The influence of perceived emotional support and competences. International Journal of Entrepreneurial Behavior and Research 25 (6):1368-1388.

Tambunan T. 2010. The Indonesian experience with two big economic crises. Modern Economy $1(3): 156-167$.

Warnke P. 2016. Opening up The Innovation System Framework Towards New Actors and Institutions. Fraunhofer ISI Discussion Papers Innovation Systems and Policy Analysis no. 49.

Wicker C, Davidsson P. 2015. The entrepreneurial break-up: Disengaging from the start-up phase. PubFactory: Research Handbook of Entrepreneurial Exit. https://doi.org/10.4337/97 81782546979.00017.

Winnen CJ. 2005. To be or not to be: The role of passion and obsession in the entrepreneurial process. [Unpublished doctoral dissertation]. University of St. Thomas, St. Paul.

[WEC] World Economic Forum. 2014. Entrepreneurial Ecosystems Around the Globe and Early Stage Company Growth Dynamics.

Vallerand RJ et al. 2003. Les Passions de l' Ame: On obsessive and harmonious passion. Journal of Personality and Social Psychology 85(4):756-767. https://doi.org/10.1037/00223514.85.4.756.

Varis M, Littunen H. 2010. Types of innovation, sources of information and performance in entrepreneurial SMEs. Journal of Innovaation Management 13(2):128-154. https://doi. org/10.1108/14601061011040221. 